The European Journal of

\title{
Is parody dangerous?
}

\author{
Sergey Troitskiy \\ Herzen State Pedagogical University of Russia, Russia \\ sergtroy@yandex.ru
}

\begin{abstract}
This article arose from the scandal which broke out in Russia in 2018, when Ulyanovsk cadets made an amateur video clip parodying the Benny Benassi's musical video (2003). Soon, this video had more than a million views. But official Russian media sharply reproached the cadets' performance, and even Russian authorities discussed the video. The Russian Internet community issued a lot of videos in support of the cadets. The reaction of Russian media on the cadets' parody was mainly strong and not always adequate. I am interested in the reasons behind the fear of parody because, in my opinion, the official discourse had nothing to fear. My analysis is based on the Russian theories of parody and the medieval cultural experience. Can parody be dangerous? Why did the official media overreact?
\end{abstract}

Keywords: parody, Ulyanovsk cadets, Benny Benassi, Satisfaction Challenge

\section{Introduction}

Parody is a customary and even commonplace element in our daily life. It does not always have a specific object but represents a "dialectical play with technique" (Tynyanov 1977a/1919: 226), demonstrates "the tension between the potentially conservative effect of repetition and the potentially revolutionary impact of difference" (Hutcheon 2000: XII, 77), and reveals "the conventionality of the system" (Tynyanov 1977b/1929: 302). That is why "everything can be parodied: a person's mannerisms and actions, his gestures, gait, facial expressions, speech, professional habits, and professional jargon. Not only can humans be parodied, but so can the material things they create" (Propp 2009/1976: 60; see also Hutcheon 2000: 18-19). Even parody or parodist themselves can be parodied. The mechanisms of parody do not change, but its object does. A parody is implemented only as an object that "is turned in upon itself, (...) is introverted and introspective, curious about its own being" (Kiremidjian 1969: 233). This isolation of parody's content allows us to characterize it as the "concept of 'second aspect' and 'doubling"" (Freidenberg 1976/1926): "the second voice, once having made its home in the other's discourse, clashes hostilely with its primordial host and forces him to serve directly opposing aims" (Bakhtin 1984/1963: 193). At the level of pragmatic perception, this isolation takes the form of the "double-voiced discourse" (Bakhtin 2000/1929: 94-96; Hutcheon 2000), where "the relationship between the author's and the other person's aspirations remains the 
same: these aspirations pull in different directions, in contrast to the unidirectional aspirations of stylization, narrated story, and analogous forms" (Bakhtin 1984/1963: 194). The content of a parody completely depends on the object: the parody assumes its form. This phenomenon can be regarded as a kind of parasitism on the object in semantic perspective, and since the object is (generally speaking) an environment of a thing or creation, the parody uses the principle of mimicry (Kozintsev 2010: 137-160). However, from the pragmatic perspective, parody could be characterized as a form of "(auto-)reflexivity" (Hutcheon 2000).

This quality can become a reason to take parody seriously and interpret it as a stylization (Tynyanov 1977a/1919: 201; Bakhtin 1984/1963: 193-194), which is why it can seem rather dangerous and entail trouble for the parodist. The most basic negative reaction is resentment, which can sometimes take collective forms. In some cases, a way to prevent or overcome a grudge (especially in the public sphere) is to punish the parodist. However, such punishment does not in any aspect neutralize the effect of parody. Moreover, a negative reaction to a parody makes it much more effective and popular: whatever the intention of the source of negative reaction is, it forever creates in the culture (media environment) an associative link between this source (even if it is not the original object of parody but simply "takes fire on itself") and the parody. In this respect, "parody is central to what we might call the methodology of affiliation" (Caesar 1989: 229), the process of the actualization of a historical fact which turns it into a present-day event.

\section{Basic approach}

The general issue covered by this article may appear rhetorical and highly abstract. Indeed, can we easily determine whether or not parody is generally dangerous? Nevertheless, the issue is relevant in respect to the essence of parody because opinions about the necessity to restrict it in the public sphere have recently been apparent on occasion (Mendis \& Kretschmer 2013: 5, 42, 46, 63; Guibault 1998). It happens in contemporary Europe and the USA in the context of copyright protection, although "the right to parody, like the right to free speech, therefore is the natural right" (Lai 2019: 32). In several regions, parody is banned for political reasons in the context of state or social security, personal or national reputation (Lai 2019: 29-31; Woodyard 2014). However, all these cases demonstrate the intention to preserve the status quo, the existing system of notions and relationships between elements, what could be entitled "order". Thus, the general issue could be reformulated as: "Is parody dangerous for the existing order?" Therefore, the subject of this article is parody as an artistic activity and its impact on real everyday practice. The main hypothesis of the research observes the harmlessness of parody in and of itself. Parody itself is not dangerous, but the interpretation of parody in society could be a marker or an indicator of a (cultural or/and social) destruction of order, whereby the supporters and preservers of order perceive a threat to that order which is separate from the parody but transfer their fear onto the parody, attributing to it a direct destructive effect. It may wrongly seem that such a statement confronts Linda Hutcheon's postmodern interpretation of parody as "both a law and its transgression, or both repetition and difference" (Hutcheon 2000: 101). The nature of parody is based on semantic doubling. However, my interest lies in the social (pragmatic) focus of parody, i.e. parody as a social fact of political relationships. This focus allows to notice a tension around the parodying act that is interpreted by people as a unidirectional political act.

The basis for resolving the general issue is built on two cases. The first is the scandal surrounding the video parody by the Ulyanovsk cadets in Russia. The present-day official discourse in Russia considers laughter, jokes, and parody as weapons in an ideological struggle, 
in line with the previous Soviet tradition (Lunacharsky 1964) ${ }^{1}$, where all acts in the public sphere were interpreted as political (including emotions (Plamper 2009; Plamper et al. 2010)). To understand the Russian specifics of the attitude to humour, it is necessary to keep this in mind.

This article is about whether parody is dangerous or not for the social order. The material of the research is the parodic video clip by cadets of the Ulyanovsk Institute of Civil Aviation (2018). I investigate the Russian scandal surrounding the video clip in the context of the main topic of the article. Cadets parodied the Benny Benassi's musical video (2003). Their video had been watched by million users during a short period of time. But the official Russian media ${ }^{2}$ sharply criticized the cadets' performance. Even Russian authorities had discussed the video. Notwithstanding the mainly critical official position taken by the authorities, Russian internet users posted a series of videos in support of the cadets. The reaction of Russian media to the cadets' parody was immediate, robust, agitated, and not always appropriate to the level of danger it posed. Despite that, the official discourse has nothing to fear. This article endeavours to explain why the Ulyanovsk parody was interpreted as dangerous for the existing order by analysing the situation of the Russian official media which expressed such a position. I will explain the content and meaning of the Ulyanovsk parody, and why it could be construed as a source of threat. I will achieve this through the analysis of musical parodic content (Shifman 2014; Lyan et al. 2015; Covach 2005; Burns 1987; Kasha \& Hirschhorn 1979; etc) and the contemporary cultural (axiological) situation in Russia (Scheff 2006; Sánchez et al. 2009; Pikulicka-Wilczewska \& Sakwa 2015; Muravyeva 2014; Höjdestrand 2017; Novitskaya 2017; Patriotic Mobilisation in Russia 2018; Kolstø \& Blakkisrud 2018; etc). A thorough examination of this kind will enable us to find an explanation for the Russian contemporary cultural context.

However, the issue of the article is formulated in relation to parody in general; therefore it would appear to be necessary to broaden out our viewpoint, which I propose to do by turning to a medieval case. First and foremost, a number of explanatory concepts and theories of parody were based on studies of the medieval cultural experience (Bakhtin 1984/1963; Propp 2009/1976; Freidenberg 1976/1926; Smith M. 2002; Zotov et al. 2018; etc). Therefore, the reasons behind the fear of parody in general could be theoretically explained by using historical examples. Secondly, today's cultural (economic, political, etc) situation is often described as neo-medievalism or new medievalism (Friedrichs 2001; Filyushkin 2018), especially in relation to Russia (Khapaeva 2016; Khapaeva 2017; Khapaeva 2019; etc). For these reasons, it seems logical to analyse medieval experience, and to seek out the answer to our general issue in the Middle Ages.

\footnotetext{
${ }^{1}$ Humour (the comical) was in opposition to the tragic, but they are different stages of historical process (Marx 1977: 134). It looked like a metaphor to Marx but Soviet humour research of the 1950-1980s was based on such points.

2 The Russian media system has "elements of both a Western libertarian and an Eastern communitarian system. (...) Its hybrid nature conceals several paradoxes in terms of the profession itself, the media market, the liberal-authoritarian role of the state, and the political adaptation of journalists" (Pasti et al. 2015: 33). The State's monopoly was built on the public space during the last 20 years. The State controls almost all the media (except the part of social media) via 'Putin's friends' (Khvostunova \& Voinova 2009). I prefer to entitle them "official media" (Bernsand \& Törnquist-Plewa 2018) or "official media outlets" (Pikulicka-Wilczewska \& Sakwa 2015) because they function as an instrument of the executive authority rather than an independent authority. The main confrontation appears on television because of its availability to the majority of Russian population (Vartanova 2015: 130; Khvostunova \& Voinova 2009: 187-191). All the Russian television channels demonstrate surprising sameness in regard to political interpretations. The TV-journalists' opinion is always exactly the same as the Kremlin's position.
} 


\section{The Ulyanovsk cadets' parody: source and resource}

In January 2018, a scandal broke out in Russia, caused by the web publication of a home-made music video for the old Benny Benassi song "Satisfaction" which had been posted in December $2017^{3}$. In many respects, this video was no different from many other home-made music videos for this song that had been made previously by members of the Russian internet community, and which were, by the way, usually meant as a greeting on the occasion of International Women's Day (March 8th). The main source of inspiration for the Ulyanovsk cadets was a home-made video made by British cadets $(2013)^{4}$. Like their British counterparts, the Ulyanovsk cadets establish their video narration as a tour through various rooms and a corridor of a student dorm (residence), where young men move rhythmically to the musical accompaniment of Benny Benassi's track "Satisfaction". The cadets in both videos are almost nude, wearing only pants, belts (shoulder harnesses), peaked caps, and boots. They imitate doing various types of housework (ironing, washing, sweeping, repairing, etc.). The rhythmical movement of the cadets in both videos contains elements of erotic dance that look similar to twerking. In the final scene, all the participants of the video gather together in a large room, where they continue to move rhythmically. Both the British and Ulyanovsk cadets' video clips show a large group of characters (more than ten people), whereas Benny Benassi's original video clip shows only four young women. They do heavy manual labour with professional equipment (a battery drill, a masonry drill, a belt sander, an angle grinder, a heavy-duty breaker, a dual action saw, orbital sanders, a manual saw, etc.). The original video was shot in a film studio with special colour decorations. The women are very scantily clad (swimsuits, shorts, etc.), with clothes emphasizing their breasts and buttocks and showing their stomachs and thighs. The women move rhythmically but without twerking (as opposed to both groups of cadets) or any elements of erotic dance. The video clip does highlight eroticism by focusing the camera on the young women's breasts, buttocks, stomachs, and thighs. Another marker of eroticism that is exploited in the clip are drops of sweat on the tanned bodies of the women. However, markers of irony (hard manual labour in a film studio, hyperbolized eroticism, the refrain "Push me" that could be spoken either by the women or by the tools ${ }^{5}$, etc.) imply that eroticism is for fun, like in advertising (Lambiase \& Reichert 2003). In addition, the similarity between advertising and Benny Benassi's video is achieved by showing text notes about each tool that the women are using. Each note includes the name and the technical characteristics of the tool currently being shown. It looks like a parody on advertising because of the music video context and the absence of any specific brands.

The track by Benny Benassi was created as a good marketing product for popular music. It was based on a combination of hooks (Covach 2005; Burns 1987; Kasha \& Hirschhorn 1979; etc.). According to A. Kasha and J. Hirschhorn, "The hook is 'what you're selling'. Although a hook can be something as insubstantial as a 'sound' (such as Da Doo Ron Ron), "[i]deally [it] should contain one or more of the following: (a) a driving, danceable rhythm; (b) a melody that stays in people's minds; (c) a lyric that furthers the dramatic action, or defines a person or place" (Kasha \& Hirschhorn 1979: 28-29). Gary Burns distinguished more types of hooks, i.e. rhythm hooks, melody hooks, harmony hooks, lyrical hooks, instrumentation, tempo,

\footnotetext{
${ }^{3}$ https://www.youtube.com/watch?v=VcMKioS_JL8 (Date of access: 19.02.2020)

${ }^{4} \mathrm{https}: / / \mathrm{www} . y 0 u t u b e . c o m / w a t c h ? v=$ ucOhxo9ivg0 (Date of access: 19.02.2020)

${ }^{5}$ Benny Benassi's video clip refers to the problem of instrumentalization of the human body. The clip assimilates the female body in an erotic perspective to an instrument or a tool. It references feminist critics of the exploitation of the body (Whisnant \& Stark 2004; Spector 2006; O’Neill 2001). However, the ironical (humorous) accents of the clip do not allow to identify the real attitude of Benny Benassi et al. to this problem. The clip actualizes the problem as a cultural dialectical position enabling both the critics and supporters of sexinstrumentalization of the female body.
} 
dynamics, improvisation and accident, sound effects, editing, mix, channel balance, and signal distortion (Burns 1987). Most of them had been used by Benny Benassi in the track, which became very popular.

The successful video sequence superimposed on a successful audio track made the clip and track especially popular. In all likelihood, the video was made to spark a series of viral reinterpretations on the internet, since it contained a number of video hooks, i.e. the provocative element of eroticism, the humorous element, popular dance movements, elements of parody on advertising, etc. Benny Benassi's video became a meme that started a series of viral reinterpretations (Shifman 2014). However, the British cadets reinterpreted the idea and hooks of the original video. Parody is revealed as parody if a spectator compares it to the original work. Despite the fact that the video of the British cadets went viral, the original context (the army) and original scenic design gave it a parodic character that did not require comparison with the original Benny Benassi's video. On the contrary, the original video turns out to be less parodic and humorous compared to both cadets' videos. Although the Ulyanovsk video was supposed to be a viral version of the British video, the Russian historical, cultural, and political context allows us to attribute a sharp satirical subtext to the Ulyanovsk cadets' clip.

The Ulyanovsk cadets borrowed the spirit of mockery and burlesque style of the original Benny Benassi's music video (2003) ${ }^{6}$. There are several direct parodies on this video ${ }^{7}$. For example, in one such parody, elderly ladies are doing the same things that the girls were doing in the original video. This was created as a statement against ageism (in support of Equal Pay Day). That video became a parody on a parody, and its heightened parodic effect was based on the contrast between the eroticism in the original video and the elderly ladies' version. The ladies repeat the sexual movements of girls, i.e. the idea is brought to absurdity. It is from this that the parody derives its comedic force.

Both the British and the Ulyanovsk cadets' music videos were in tune with the idea of the original video and exploited (homo)eroticism, showing slender, young, and tight bodies of men in their underwear using hardware tools. However, although the video parodied some stylistic properties of Benny Benassi's video, the cadets created a new form and a new plot, used new means of expression, new symbolic series and a dramatic line (plot) that were different from that of Benny Benassi's work. That is why the British cadets' video could be interpreted as an original meme. Their video started a series of viral reinterpretations, like the Gangnam style video, e.g. "Mitt Romney Style", "NASA Johnson Style", "Egyptian Style", and many others (Shifman 2014; Lyan et al. 2015).

The Ulyanovsk video was a viral reinterpretation not of the Benny Benassi video, but rather of the British cadets' version. Furthermore, the Ulyanovsk video started a series of its own viral reinterpretations on the Russian internet. Once it was on the internet, the parody made by the Ulyanovsk cadets began to function as a post-folklore (internet-folklore ${ }^{8}$ ) work of art (Nekludov 1995; Nekludov 2002; etc.) and meme (Shifman 2014; Lyan et al. 2015). It was transmitted (shared), commented (comment), had apolitical content and became the basis for the unravelling of the plot and imitation. As with the Gangnam style video (2012), the Ulyanovsk cadets' video caused a whole host of imitations on the internet. New variants of the video by other authors, even with humorous or parodic interpretations, used the idea, the

\footnotetext{
${ }^{6} \mathrm{https}: / / \mathrm{www}$. youtube.com/watch?v=a0fkNdPiIL4 (Date of access: 19.02.2020)

${ }^{7} \mathrm{https}: / / \mathrm{www}$.youtube.com/watch?v=CX8MXqV8Zks;

https://www.youtube.com/watch?v=j4wpXSDRXk4 (Date of access: 19.02.2020)

8 On the problem of terminological definition of "post-folklore", "internet-folklore", "web folklore", "electronic folklore", "digital folklore", etc. see: Kucherenko 2016; Alekseevskiy 2010; Koiva 2009; de Seta
} 2020; etc. 
structure, and the plot of the first video clip. This was characteristic of both the Gangnam style video and the Ulyanovsk cadets' one.

The Ulyanovsk video clip also caused critical reactions on the internet. One of them was a video made by cadets of the Kremlin guards (the elite Moscow Higher Combined Arms Command School) ${ }^{9}$. In contrast to the Ulyanovsk clip, the Kremlin one has good production quality and was probably shot with professional video camera. The camera operator focuses correctly and builds the composition. The camera is static, showing the speakers from the waist up. There is only ever one cadet in the frame. The Kremlin cadets recite a poem in an official room. They are dressed in military uniforms. They present a 'poetic' critique of the Ulyanovsk cadets and of their video from a conservative standpoint.

\section{The Ulyanovsk parody: cultural context}

The video itself would probably have remained unnoticed were it not for one reason: it was made by cadets of the Ulyanovsk Institute of Civil Aviation, an institution unknown to most Russian people, but which trains pilots. Historically, all pilots and sailors in Russia are perceived as military, even if they are civil specialists. In Russia, even civilian flying schools are close to the armed forces: they are modelled after military schools, and are perceived as such (according to their web-sites). After the video was published on YouTube, the main TV channels discussed how low army morals had sunk, what punishment would be fitting for the performers, etc. ${ }^{10}$ In this way, the theme of the moral standards of the army became one of the most popular in the discussions surrounding the video clip of the Ulyanovsk cadets. Conservative commentators were shocked and downright scandalized: "Cadets, a step away from qualifying as pilots! How dare they!" The position of Russian politicians and official media is generally conservative, especially in the context of international sanctions and isolation, following 2014, which is why some media made the Ulyanovsk cadets' video the target of their attacks less than a month after it was posted online.

As a result, Russian society was divided into two parts: some insisted that the cadets should be severely punished (maybe even expelled for tarnishing the badge), while others believed that the video was a joke, a parody, and should be perceived as such. A governmental commission was set up to deal with the incident. ${ }^{11}$ As a result, the cadets were reprimanded. Almost immediately, an internet campaign was launched in support of the Ulyanovsk cadets, called "Satisfaction Challenge", where various groups of people made their own versions of the Benny Benassi video. ${ }^{12}$ At first, the campaign attracted mostly pupils and students from various educational institutions, but then other groups joined them (senior citizens, young mothers etc.). Little by little, the exploitation of eroticism diminished and the last twenty videos or so were completely free of sexual innuendo, and just reproduced the scenario of the original video $^{13}$. At the same time, several commercial videos appeared: they exploited the popular

${ }^{9} \mathrm{https}: / /$ www.youtube.com/watch?v=51Thm05mS44 (Date of access: 19.02.2020)

${ }^{10} \mathrm{https}: / /$ www.youtube.com/watch?v=8xOJgAY3r2o;

https://www.youtube.com/watch?v=RGjQcUUXbbA; https://www.youtube.com/watch?v=VdgQDvhX0-Q

(Date of access: 19.02.2020)

${ }^{11}$ Vladimir Zhirinovsky was an exception in the general stream of criticism:

https://www.youtube.com/watch?v=iH-C7AFEIrw (Date of access: 19.02.2020)

$12 \mathrm{https} / / / \mathrm{www}$.youtube.com/watch?v=qrevWmkJHkE;

https://www.youtube.com/watch?v=CBQ6qIfKXWY; https://www.youtube.com/watch?v=uNhmZYNwrtY; https://www.youtube.com/watch?v=Po44xkW6XGE (Date of access: 19.02.2020);

${ }^{13} \mathrm{https}: / /$ www.youtube.com/watch?v=ZXWsVZzbUFI; https://www.youtube.com/watch?v=deLadfHis5s; https://www.youtube.com/watch?v=NLVdnZS-3bQ (Date of access: 19.02.2020); 
topic but were clearly shot for promotional purposes (employees of different commercial organizations were doing their usual work while rhythmically moving to the music of the composition and showing the logos "Challenge" and their own corporate brands) ${ }^{14}$. However, this attempt to take advantage of the opportunity did not cause any stir. In total, more than fifty different video reactions to the cadets' video were produced, including clips from abroad (from Israel, Latvia, and elsewhere).

I do not know what motivated the Ulyanovsk cadets to shoot their video but it is apparent that they wanted to remake the video of their British counterparts. The Ulyanovsk version can also be described as one of the parodies that preserved the humorous zeal of both Benny Benassi's original video and that of the British cadets. It was shot in the student hall of residence, during the students' free time.

In Benny Benassi's video, the humorous effect was achieved mainly through the discrepancy between the stereotypes - conventional "masculine" manual labour was performed by "weak" girls, clearly models, obviously inappropriately dressed and demonstrating their "femininity". The Ulyanovsk cadets also enhanced the humorous contrast through violation of the same stereotype, but in reverse: conventionally "female" housework was performed by butch, masculine men. This masculine image was reinforced by another detail: the future pilots were wearing only their underpants, peaked caps, and shoulder harnesses, thus making a direct reference to the image of military men. This element added a new level of humour: the discrepancy between the image of military men and peaceful housework which all the cadets performed in the music video.

The humorous contrast between masculinity and the 'female' housework exaggerates the cadets' masculinity. This aspect is noticeable in the cadets' clips (British and Ulyanovsk alike), just as the exaggeration of femininity is noticeable in the Benny Benassi video. All the cadets demonstrate their hypermasculinity (or macho image), reproducing the "hypermasculine pattern" (Scheff 2006; Sánchez et al. 2009) and exploiting media stereotypes on masculinity. The image of the military man is hypermasculine in itself. However, in the video clip, there is also hypermasculinity in the context of eroticism. Then, the resultant image could be interpreted as both heterosexual and homosexual (e.g. BDSM / gay subculture). Moreover, the homosexual aspect of hypermasculinity was captured by Tom of Finland, Gengoroh Tagame, and others. They created a series of classical images that are used by popular culture, advertising, and media to depict the masculine man. The images have become a cultural marker of masculinity and are picked (read) by members of all cultures without the need for special comments. The key point of the new Russian conservative identity is the traditional family. Russian conservative people do not accept "non-standard sexualities" (Pikulicka-Wilczewska \& Sakwa 2015: 192), hyperbolized eroticism, and homosexuality because they are opposed to the traditional family (Muravyeva 2014; Höjdestrand 2017), but while the first is interpreted as implying a low level of morality, the second causes fear because homosexuality is still treated like a genetic mutation or a (contagious) disease (Gorbachov 2014; Storn 2018; Kondakov 2018). The visual elements of the aforementioned images are reproduced in the video (tight briefs, belt (shoulder harness), a peaked cap, and boots), which is why Russian official media and politicians were so alarmed by the Ulyanovsk cadets' video.

The video itself was not merely a copycat reproduction: the Ulyanovsk cadets grasped the original joke and then creatively elaborated upon it. Furthermore, they created their own dramatic dynamics (stairs - corridor - bath - toilet - work zone, etc.), a new cultural context, and new accents (the anonymous sexual person in the context of a cheap home-made video).

\footnotetext{
${ }^{14}$ https://www.youtube.com/watch?v=zyMlsKFEef8; https://www.youtube.com/watch?v=7aR26DnBXRY; https://www.youtube.com/watch?v=DwNHc_1tHcQ; https://www.youtube.com/watch?v=be8QG81K3Tw (Date of access: 19.02.2020)
} 
The result was a creative parody of Benny Benassi's original humorous music video, which happened to receive a new meaning in the Russian cultural context. It could be interpreted as a parody on masculinity. But was it that simple?

\section{The Ulyanovsk parody: political aspects}

Although formally (and de jure) "parody is imitation. (...) parodist takes from, or if you wish 'copies', parts or aspects of another expressive work" (Posner 1992: 67), even copyright law (let alone other branches of law) does not regard parody as a violation of intellectual property rights. Nevertheless, parodies quite often become the target of, if not legal, then ethical and political assessment.

Given the vivid militaristic rhetoric in present-day Russia, stimulated by patriotic (conservative) mobilization (Patriotic Mobilisation in Russia 2018; Kolstø \& Blakkisrud 2018), it is not surprising that the music video was perceived as a parody on the armed forces. This was the interpretation presented by the official media. Moreover, given that there is also a very powerful moralizing discourse inherent in any radical right- or left-wing ideology, it is not surprising that people saw in the video a mockery of moral principles. Furthermore, ever since the time of Aristotle, parody has often been interpreted as a depiction of people as "worse than they are" (Aristotle 1922: 11, fragment 1448a), and such an opinion is commonplace. Besides, parody (and humour in general) is considered by non-specialists in humour studies as direct action. The official discourse in the Russian media has formed a generalization: any parody on the army, police, etc. is a parody on strength, i.e. a parody on masculinity. But there is an interesting paradox in their logic: if the Ulyanovsk parody is dangerous to masculinity and strength, then both must be weak. In other words, weakness is one of the characteristics of strength and masculinity. ${ }^{15}$ However, the paradox and fear of parody "uncovers the signs of masculinity in crisis", "male hysteria" (Novitskaya 2017: 302). In other words, the problem (the focal point of the fear) is not in the parody itself, but rather in the subject who views the parody.

Because of the polarised ideological opposition within Russian society, subjects read messages in the media space as being political. Where "liberal people" see freedom, liberal emancipation, and human rights, "patriots" and "conservative agents" perceive a threat to traditional values. That is why it is not surprising that the second group was represented also by cadets, but the cadets of the Kremlin guards (The Moscow Higher Combined Arms Command School) ${ }^{16}$. However, both "liberal" and "conservative" political agents acknowledge the effectiveness of parody and laughter. Moreover, according to Linda Hutcheon, "parody is fundamentally doubled and divided; its ambivalence stems from the dual drives of conservative and revolutionary forces that are inherent in its nature as authorized transgression" (Hutcheon 2000: 26).

Thus, the video-parody was regarded as a direct political statement, undermining the very foundations of the state. This situation is not specific to Russia. For example, in China, there is a television ban in place: humorous videos and parodies on works of art are prohibited because such content "undermines the basic principles of socialism" and could threaten the authority of the Chairman $\mathrm{Xi}$ Jinping. According to the Communique of the General Administration of Press and Publication, Radio, Film, and Television, the country bans any videos that "distort, mock or defame classical literary and artistic works" (which generally

\footnotetext{
15 Which is why masculinity needs anything that could be a marker of strength, and the embodiment of a masculine image is a gunner or hunter.

${ }^{16} \mathrm{https}: / / \mathrm{www}$. youtube.com/watch?v=51Thm05mS44 (Date of access: 19.02.2020)
} 
means the creation of parodies).

But is parody really that dangerous, and does it undermine anything? Is it correct to regard any antireferential message from "the Third world of reference" (Kozintsev 2008) as a direct statement?

\section{From neo-medievalism to medieval experience}

By the end of the 20th century, "conversations on medievalism in the full spirit of Foucault or Barthes shifted the epicentre of research questions from a striving for objectivity to the problematics of the politics of knowledge - of those relationships which underpin knowledge with its own objects, and of the social effects which knowledge about the medieval period in contemporary society could have" (Savitskiy 2015: 348), and this was to become the basis of the formation of neo-medievalism or new medievalism (the term is not fixed as yet) both as an academic discipline (Freedman \& Spiegel 1998; Brownlee at al. 1991; Bloch et al. 2014) and in everyday political practice. Contemporary Russian culture "cannot be accurately assessed without understanding its connection to a specific post-Soviet form of neo-medievalism" (Khapaeva 2017). It is a complex set of ideological statements which combines apology of the terror of the past as a way of explaining the violence and cruelty of the contemporary State (Holsinger 2007), neoconservatism (Holsinger 2017; Elliott 2017; Eco 1986), isolationism (Wollenberg 2018: 23-40), hierarchism (Khapaeva 2017), antidemocratism and post-liberalism (Eco 1986; Eco 1998), and neo-feudalism (Åslund 2019; Wollenberg 2018: 65-86; Neckel 2010). An additional marker of neo-medievalism is the multitude of medieval images and metaphors, (pseudo-) ancient words and syntactic constructions in (visual) rhetoric (Robinson \& Clements 2012; Eco 1986). Discursive practices of neo-medievalism are based on the discourse of the Invisible, where minority policy is discriminated against (Deets 2006) ${ }^{17}$, the fear of an invisible enemy facilitates the consolidation of society (Holsinger 2007), (secular) theology is the grammar of thinking (Holsinger 2008; O'Callaghan 2013; Cox 1984; Robbins 2019), and seriousness - often based on religion - is a form of non-critical consciousness (Corriveau et al. 2015). Because theology took centre stage in the Middle Ages "and there has never been anything as serious as that" (Rosselli \& Besomi 2005: 311) ${ }^{18}$, seriousness seems to be an indispensable attribute of the Middle Ages (Digby 1894), although this stereotype is a result of the influence of romanticism. Such a perception of the Middle Ages was strengthened by Bakhtin's conception of medieval official culture (Bakhtin 1968/1965).

In Russian culture today, I observe a serious attitude to parody and laughter, a tendency towards gelotophobia (Ivanova et al. 2017) that could be explained by the strongly hierarchical character of Russian society, where "shame is one of the main mechanisms of social control" (Ivanova et al. 2017: 86; Davies 2009). In official media, any humorous statement (in the broad

\footnotetext{
${ }^{17}$ Minority policy is considered by the European juridical system as a foundation of international peace and security in the post-Westphalian period. "The grand bargain of Westphalian sovereignty, though, has been that states are recognized as independent entities with power over their people to the extent that they do not violate certain rights of minorities. If norms are violated, the international community has the collective right to intervene. This bargain is rooted in fears of prolonged violence. (...) Given that interventions of one state into another were increasingly framed in terms of protecting co-religionists and the resulting 'religious' wars were incredibly destructive, the Treaties of Westphalia and, by the mid-eighteenth century quite a number of other international treaties, modified the cuius regio, eius religio standard by including broad provisions for states to tolerate different Christian faiths on their territory as a way to increase international stability. (...) Since World War II, the substance of minority policy norms has combined the perspective of liberal individualism with increasingly detailed requirements of state-provisions of public goods" (Deets 2006: 20, 24; Krasner 2001).

${ }^{18}$ This is an extract from the Piero Sraffa's letter to Dennis Robertson (October 31, 1932) cited by (Rosselli \& Marcuzzo 2005).
} 
sense) "has always had a political dimension" and is often interpreted as political satire (a critical political statement) but it is only "the appearance of political satire" (Tagangaeva 2013: 11, 16). Moreover, "one and the same popular Russian comedians wander from one show to the next, from one network to another, thereby replicating one and the same comedic images, and together with them, specific values and views" that strengthen the "state-controlled censorship on Russian networks" (Tagangaeva 2013: 16). It seems that the authorities believe that they need to be on their guard, and that it is best to completely suppress or localize such humorous statements. However, as history shows, such an aim can be hard to realize successfully ${ }^{19}$.

The concept of neo-medievalism allows us to understand contemporary Russian political discourse and the pattern of contemporary Russian culture because this concept is planted in the very foundation of contemporary Russian political practice (Khapaeva 2017). However, neo-medievalism is "fantastic medievalism" (Eco 1986: 69), a construct which simplifies the medieval past. It is a foundation for building the politics of memory, but it has little to do with medieval reality, especially where medieval parody is concerned. Especially, it is applicable to the theory of parody in a postmodern theoretical context (Hutcheon 2000). It seems erroneous to consider parody (or any other humorous utterance) as direct action because parody is not a "naked rejection of the parodied object" (Bakhtin 1984/1963: 127) and "it is a bad idea to use parody as a source of knowledge about the reality to which the original refers or even about the original itself" (Kozintsev 2010: 34). Parody sets off a variety of cultural processes of interpretation and, as a result, the object of the parody should not necessarily be regarded as something negative (for that to happen, specific external circumstances of the parodic message are required) (Ouidade \& Géraldine 2014). It is only when the object of the parody itself causes negative emotions, prior to the act of parody, that these emotions will intensify. In this sense, the perception of parody in the Middle Ages seems much more appropriate to the situation: during that historical period, parody took its own important place alongside phenomena that were themselves quite serious, even terrible, for a representative of modern culture ${ }^{20}$. "In the Middle Ages, under cover of the legitimized license of laughter, parodia sacra became possible - that is, parody on sacred texts and rituals", as Mikhail Bakhtin notes (Bakhtin 1984/1963: 127; Hutcheon 2000). And even though parody was, for example, an instrument of the "apophatic" arguments of the Cynics (Svetlov 2019), and is found in the words of Socrates (Svetlov 2015; Svetlov \& Savchuk 2017), it is nevertheless Medieval parody which formed the basis for constructing the theory of parody.

\section{Was parody dangerous for a medieval person?}

In describing parody, both Olga Freidenberg and Mikhail Bakhtin make reference to the Middle Ages, thereby exploding the myth of the totality of seriousness and suffering, religiosity and asceticism in this period of European history. They cite numerous examples which testify to the coexistence of two cultural realities, or two modes of existence. But this phenomenon is peculiar not only to secular literature, and indeed not only to medieval literature. For example, in his famous second sermon "The House of Feasting and the House of Mourning Described", Laurence Stern states: "Sorrow (...) has no use, but to shorten a man's days - nor can gravity,

${ }^{19}$ For example, in spite of difficulties with humour about Stalin, folkloric humorous works were in fact created and distributed (Krikmann 2009; Krikmann 2004; Davies 2007; Kozintsev 2009; Arkhipova \& Melnichenko 2009; Oushakine 2011).

${ }^{20}$ For example, Moira Marsh (Smith) finds a parodic aspect even in "Malleus Maleficarum or Hammer of Witches", the book on demonology by Dominican Inquisitor Heinrich Kramer (Smith 2002). 
with all its studied solemnity of look and carriage, serve any end but to make one half of the world merry, and impose upon the other" (Sterne 1760: 45-46). As Freidenberg points out, such a coexistence is characteristic of the medieval Christian outlook. This idea of Freidenberg is confirmed by numerous examples cited by the authors of the recent book "The Suffering Middle Ages" (Zotov et al. 2018) and the book "Monsters and Grotesques in Medieval Manuscripts" (Bovey 2002). Exploring medieval manuscripts, they find illustrations on the margins full of mockery and the grotesque. What is more, they found them more often "not in chivalric novels or courtly poems, but in psalteries and books of hours" (Zotov et al. 2018: 31). Any story or character, including priests and saints, could become the object of a humorous image of this kind. And as we are speaking here about rather expensive books, one might think that such a dichotomy arises only in the culture of intellectuals, i.e. to use Bakhtin's term, in the "official" or "high" culture, but if this idea is accepted, then Bakhtin's concept, according to which social stratification underlies the division of the national culture into the official and popular culture, will be effectively destroyed. Some critics indeed reproached Bakhtin, for he described intellectuals ${ }^{21}$ even when talking about popular (folk) culture (Hutcheon 2000). However, if we study certain literary (or artistic) works which were truly intended for the average, unsophisticated person, who could not buy expensive books, let alone read them (in Latin), we will see the same dichotomy. The system of ecclesiastical visual images intended to be "read" by uneducated worshippers (Gregory the Great (590-604) had called it "the great bible of the illiterate" or "the scriptures for simpletons") demonstrates the same coexistence of parody and its object, the serious and the ridiculous, the official and the popular, the spiritual and the corporal (gargoyles and other monsters on the facades and inside the temple, various semantic references to carnal relations, sinners, etc.).

Even such a popular medieval image as the "danse macabre", or dance of death (the "Totentanz") is a parody. The object of this parody is

the ideal celestial messenger - an angel who lugs away a soul, a winged genius with an extinct torch, or a mourning woman - who in the XV century was replaced by the ugly messenger of hell. (...) She is devoid of gloomy strength and greatness, she dances, plays, sings mocking couplets (...) Her antics, bows, gentle embraces, insinuating smiles, and derisive invocations - everything testifies to her devilish, clownish nature. On the early frescoes of Basel, Lübeck, Bern, she appears as a thin corpse, dressed in a smudged leotard, with obviously painted ribs and a mask of the eyeless skull. ${ }^{22}$

(Ioffe 1934: 68)

At the same time, the objects of the parody are the people who believe that certain privileges and protective measures can save them from death.

The final hour arrives suddenly - hence the comic effect of surprise. It strikes equally both young and old, rich and poor - hence the ridicule aimed at those who believed themselves protected by age, rank, or fortune. (...) They do not, however, stigmatize these people (were they not so ordered by God?) but rather point out the laughable illusions that honors and money engender in the wellto-do.

(Delumeau 1990: 86-87)

Delumeau draws attention to the mystical origins of this image, which sprang from actual mysteries and rituals. "Mâle argued that the oldest danse macabre may have been a mimed

${ }^{21}$ Meaning people who could read in Latin and could use any (monastic) book depository because they constitute a very small community in Europe (Bovey 2007).

${ }^{22}$ See also: Sychenkova 2001; Slepukhin 2013. 
illustration of a sermon on death. Danced at first in church, it would have then been danced outside on a stage as a sort of morality play, as happened in Bruges in 1449 at the 'Hôtel' of the Duke of Burgundy" (Delumeau 1990: 73).

The events depicted by Delumeau, including various holidays for which parody was essential (Feast of the Ass, Fool's Day, St. Innocents' Day, etc.), had been described in Olga Freidenberg's article "The Idea of Parody" that parody is a necessary element of the dichotomy of medieval European culture. Although they are not limited to medieval culture, Freidenberg also reminds her readers about the "Batrachomyomachia" or "the mysterious scenes from Aristophanes' writings, when only the context makes the original epic formulas and sacred hymns comical" (Braginskaya 2016: 46). Here we can also recall the trickster, an essentially parodical figure. The trickster always refers to originality and normativity, while, at the same time, distorting and embellishing them (Troitskiy 2008; Troitskiy 2006; Troitskiy 2011). However, our ideas about normativity are very different from those held in the Middle Ages.

The Middle Ages (a huge span of time, roughly 470-1500) was firmly under the sway of the Holy. Despite using plenty of words that we would today consider shocking and offensive, medieval English people were unconcerned about the Profane. Instead, swearing was the most highly charged language - the truly obscene - and was thought to be capable of injuring God's reputation and even physically assaulting Christ. During the Renaissance (c. 1500-1660), the Holy and the Profane were more in balance. The rise of Protestantism and its changing definition of people's relationship to God, as well as the growing importance of "civility," created conditions for the development of obscenity, one of the things that proper, polite behaviour is defined against.

(Mohr 2013: 4-5)

The authors of "The Suffering Middle Ages" also emphasize an important characteristic of parody: the images on the margins do not create a whole world; the place of the whole world is the middle of the page. Any attempts to interpret all the parodies together as elements of a single world will be unsuccessful, as each parody is connected with a specific initial object of parody.

In many manuscripts, marginalia, no matter how far they are from the text, are in fact illustrations, commentaries, parodies, or the response of another kind. (...) Not infrequently, marginalia are not illustrations, comments, or parodies of some fragments of the text: they snatch out specific words (a text mentions "night" - and there is a bat on the margins) or even syllables.

(Zotov et al. 2018: 46)

Context (or "background", according to Tynyanov ${ }^{24}$ ) provides parody with the possibility to exist: without context, there can be no parody. Parody disappears as soon as its context disappears from the field of view of the reader or viewer: in this case, parody becomes an independent work, a new form of blasphemy, depending on a fresh point of view.

Parodies ridiculing liturgy or other serious genres are also characteristic of Russian culture ("The Tale of Woe and Misfortune", "The Sermon on the Hop", "The Liturgy of the Tavern",

23 This article was published in 1926 in a typewritten collection commemorating the anniversary of the scholarly works of S. A. Zhebelev. There were three copies of the collection: two for libraries and one for the hero of the day. Today, two copies are stored in the main libraries of the country (in Moscow and St Petersburg). In the Russian National Library, it is kept in the Department of Manuscripts; thus, it can be deemed inaccessible. In 1973, in Tartu, the draft of the article was published as an independent work (Freidenberg 1973/1926) and then translated into English (Freidenberg 1976/1926).

${ }^{24}$ Tynyanov writes, "Stylization is close to a parody. Both live a double life: behind the plan of the work is another one, stylized or parodied" (Tynyanov 1977a/1919: 201). 
"The Tale of Foma and Erema", various satirical poems, woodcuts, street performances about Petrushka, and so on).

Both Bakhtin and Freidenberg perceive parody as a purely comical genre: it mocks tragic or serious cultural models (prototypes). On the contrary, Tynyanov believes that parody breaks away from comedy, since it is just one of the various stages in the evolution of literature (or culture). However, is it possible to identify parody with comedy? It does not seem so. Although, according to Freidenberg, comedy and tragedy share common roots, they are independent cultural forms. Aesthetic categorization makes it possible to counterpoise them as "high" or "low" (Freidenberg 1997/1954) but they act as generally independent elements of culture; structurally similar, they exist separately. And although comedy employs techniques of parody (or probably the other way round because comedy is definitely a broader term than parody), it is, nevertheless, still a method of diminishment. Parody thrives on its object. It does not create the whole but exists by feeding on specific features of the object and hypertrophying them. In this sense, it is possible to mock either a parody or a comedy. Here, laughter can be a reaction both to a secondary parody and to an original comedy, which has itself become an object of parody. Parody does not destroy the model (prototype), and that is why I disagree with all three aforementioned authors.

It is important to understand that parody always finds itself at the margins (of a text, image, or culture). It cannot occupy a central place due to its dependent, supplemented status. It cannot become an organizing principle of culture but it can limit that culture, revealing the boundaries of its core concepts.

In this sense, Bakhtin's culture of laughter (or popular culture) is just a reference, and not to a whole culture but to a strategy. Bakhtin's concept implies that parody, comedy, and laughter (in Bakhtin's view, they are identical characteristics of popular culture) comprise an opposition or a rival to official culture. However, how can it, being so dependent, be a proper replacement for its object? How can disparate elements replace the whole, how can a parody of a feature destroy the object to which this feature belongs? Neither the social stratification underlying the distinction between the official and the popular in Bakhtin's works, nor the variations of forms that lay the foundations for Tynyanov's literary evolution (that is, their concepts) can be destroyed by parody. As Freidenberg has demonstrated (Freidenberg 1976/1926), "official" culture will not become less serious, solemn, and pretentious if it is subjected to parody, and it certainly will not seek self-destruction, as Tynyanov taught. According to Tynyanov, tragedy will not lose its tragic nature. Catholic clerics were replaced by Protestant pastors not because their sins had been ridiculed but because of those very sins, while the social stratification prevailed. Russian poets, whose linguistic archaisms became the object of parody, created one of the stages in the history of literature under the name "archaists" but the literary device always remained the same.

Medieval studies reveal a fairly clear understanding of the role of parody: "Degradation, decline, temporary swallowing, slipping to the lower stages of development - all this serves as the leitmotif of the parody, and humour, and archaic holiday ceremonies, and myths of the trickster cycle. All these, as it turns out, relate primarily to the subject himself and not to the objects of his perception, real or fantastic" (Kozintsev 2013: 156). Despite the totality of the ethical discourse built on Christian dogma, parody was a part of medieval life ${ }^{25}$; it functioned mainly as folklore with which the Church had to put up. At the same time, the official discourse developed a neutral attitude to parody and, in the main, legitimized it. "Like the sixteenth century, the postmodern period has witnessed a proliferation of parody as one of the modes of

25 Undoubtedly, in official medieval documents, one can find quite different assessments of laughter, humour, and parody, some of them negative; but even special penalties aimed at parodists could not eradicate parody as an element of culture. 
positive aesthetic self-reference as well as conservative mockery", Linda Hutcheon noticed (Hutcheon 2000: 82).

Parody always accompanies all serious and tragic phenomena but it does not threaten them. Parody alone does not threaten order; on the contrary, it is a universal practice allowing for the establishment of order ${ }^{26}$. The only exception is when the order itself is decomposing. In this case, parody could be used for the acceleration of the destructive process, and could be interpreted as satire.

\section{Conclusion}

Compared to other periods in cultural history, the study of medieval attitudes to parody has perhaps been the most comprehensive. It was on the basis of the results of these studies that, in the 1920-1930s, the theory of parody was developed - a theory that allows for the elimination of the possibility to influence the object of parody directly. In spite of this, everyday consciousness presupposes the direct influence of the "third world of reference" (humour, parody) on the "first world of reference" (reality), bypassing the "second world" (the world of art) which lies between them (Kozintsev 2008). In other words, parody is regarded as stylization, and the phenomenon depicted (personality, plot, etc.) is considered as a real object of parodical imitation (style, genre, form); the antireferential (parodical) storyline and the antireferential (parodical) fictionality (which are reproduced in formal concordance with the sample) are passed off as reference or even reality. Therefore, it is also tempting to exclude and avoid parody.

In the space of strict regulation and total control (the vertical of power) in Russian society, free action which does not fall under the rules and does not subject itself to them is regarded as a violation. In this case, power acquires the character of a direct prohibition of everything which is not allowed, and politics becomes a strategy of control over everything that is not amenable to regulation. Power is distributed from a single source, and is scattered among agents who become "instances of power", implementing their own image of the "source of power" 27 , according to their own ideas about it ("The retinue makes the king") 28 . The Ulyanovsk cadets who remade the video of the British cadets, and scarcely had any plans at all to impinge on the foundations of the state, found themselves in a situation where their amateur video, which was itself a parody of Benni Benassi's video, came into collision with the authorities' image of the source of power, its patterns and normative constructions. It was these instances of power that saw the parody as dangerous, attributing their own fears and ideas to the source of power. The system of imaginary patterns and normative constructions of a single source of power strengthens the legal principle "Omnia non licet prohibitur" ("Everything that is not allowed is forbidden"), or rather, it is the only tool for the implementation of this principle. Parody and disorder do not bear any direct correlation to each other. Parody is not opposed to order or cultural models, nor does it pretend to replace them with itself because parody does not exist as parody without the model and the (cultural or/and social) order, and "might be said to be, at heart, less an aggressive than a conciliatory rhetorical strategy, building upon more than attacking its other, while still retaining its critical distance" (Hutcheon 2000:

\footnotetext{
${ }^{26}$ Christie Davies demonstrated the unstable and not guaranteed effects of humour on "social reality", and the absence of a direct correlation between ridicule and social effect (Davies 2011; Davies 1998).

${ }^{27}$ On the conceptual difference between the functions of a "source" and an "instance" see: Troitskiy 2018 : 191-196.

${ }^{28}$ The action mechanisms of the instances of power, who envision what the single source of power is and then independently exercise that power in accordance with this idea, are described by F. Kafka (on this see: Logutov 2017: 66-76).
} 
XIV). Parody itself is not dangerous, however the interpretation of parody in society might be a marker or an indicator of the destruction of the (cultural or/and social) order, when the supporters and preservers of that order perceive a threat to it which is separate from the parody but transfer their fear onto the parody and attribute a direct destructive effect to it.

\section{Acknowledgements}

The article was written with the financial support of the RFBR (project № 18-011-00570 A). Special thanks to Maria Semikolennykh and Chris Gilbert for their linguistic professionalism, and to Liisi Laineste, Alyona Ivanova, and Dina Khapaeva for their advice and attention.

\section{References}

Alekseevskiy, M. D. (2010). 'The Internet in the folklore or the folklore in the Internet: Modern folkloristics and virtual reality', in Dobrovolskaya V. E. \& Kargin A. S. (eds) Ot kongressa $k$ kongressu [From Congress to Congress]. Moscow: Gosudarstvenniy respublikanskiy center russkogo folklora, pp. 151-166.

Åslund, A. (2019). Russia's Crony Capitalism: The Path from Market Economy to Kleptocracy. New Haven and London: Yale University Press.

Aristotle (1922). The poetics of Aristotle. London: Macmillan.

Arkhipova, A. S. \& Melnichenko, M. A. (2009). Anekdoty o Staline: Teksty, kommentarii, issledovaniya [Stalin jokes: texts, commentary, and analysis]. Moscow: OGI, RGGU.

Bakhtin, M. M. (1968 [1965]). Rabelais and His World. Trans. Hélène Iswolsky. Cambridge, MA: MIT Press.

Bakhtin, M. M. (1984 [1963]). Problems of Dostoevsky's Poetics. London: University of Minnesota Press.

Bakhtin, M. M. (2000 [1929]). 'Problems of Dostoevsky's works' [Problemy tvorchestva Dostoevskogo], in Bakhtin, M. M. (ed.), Collected Works. Vol. 2. Moscow: Russkie slovari, Yazyki slavyanskoy kultury, pp. 5-175.

Bernsand, N. \& Törnquist-Plewa, B. (eds.) (2018). Cultural and Political Imaginaries in Putin's Russia. Leiden, Boston.

Bloch, R. H. et al. (eds.) (2014). Rethinking the New Medievalism. Baltimore: Johns Hopkins University Press.

Bovey, A. (2002). Monsters and Grotesques in Medieval Manuscripts (Medieval Life in Manuscripts). Toronto: University of Toronto Press.

Bovey, A. (2007). 'Renaissance bibliomania', in Woods, K. W., Richardson C. M. \& Lymberopoulou, A. (eds.), Viewing Renaissance Art. New Haven: Yale University Press, pp. 93-129.

Braginskaja, N. (2016). 'Binômes, opposition, répétition, contraste: Les racines mythologiques des catégories esthétiques d'Ol'ga Frejdenberg'. Revue des études slaves LXXXVII/1, pp. $35-51$.

Brownlee, M. S., Brownlee K. \& Nichols S. G. (eds.) (1991). The New Medievalism. Baltimore. London: Johns Hopkins University Press.

Burns, G. (1987). 'A typology of "Hooks"', Popular Records. Popular Music. 6 (1), pp. 1-20.

Caesar, T. P. (1989). 'Joycing parody'. James Joyce Quarterly 26 (2), pp. 227-237.

Corriveau, K. H., Chen E. E. \& Harris P. L. (2015). 'Judgments about fact and fiction by children from religious and nonreligious backgrounds'. Cognitive Science 39 (2), pp. 353-382.

Covach, J. (2005). 'Form in rock music: A prime', in Stein, D. (ed.), Engaging Music: Essays in Music Analysis. New York: Oxford University Press, pp. 65-76. 
Cox, H. (1984). Religion in the Secular City: Toward a Postmodern Theology. New York: Simon and Schuster.

Davies, C. (2011). Jokes and Targets. Bloomington: Indiana University Press.

Davies, C. (1998). Jokes and Their Relations to Society. Berlin; New York.

Davies, C. (2007). 'Humour and protest: Jokes under communism'. International Review of Social History 52, Supplement 15, pp. 291-305.

Davies, C. (2009). 'Humour theory and the fear of being laughed at'. Humor: International Journal of Humor Research 22 (1/2), pp. 49-62.

Deets, S. (2006). 'Pulling back from neo-medievalism: The domestic and international politics of the Hungarian status law'. Slavic Eurasian Studies 9, pp. 17-36.

Delumeau, J. (1990). Sin and Fear: The Emergence of a Western Guilt Culture, 13-18th Centuries. New York: St. Martin's Press.

Digby, K. H. (1894). Mores Catholici: Or, Ages of Faith. New York: P. O'Shea.

Eco, U. (1986). 'Dreaming of the Middle Ages', in Eco, U., Travels in Hyperreality. San Diego, NY, London: Harcourt Brace Jovanovich, pp. 61-72.

Eco, U. (1998). 'Living in the New Middle Ages', in Eco, U. Faith in Fakes: Travels in Hyperreality. London: Vintage, pp. 73-86.

Elliott, A. B. R. (2017). Medievalism, Politics and Mass Media: Appropriating the Middle Ages in the Twenty-First Century. Woodbridge: D. S. Brewer.

Filyushkin, A. I. (2018). 'Medievalism: why do we need the Middle Ages today?'. Historical Expertise 4, pp. 153-162. DOI 10.31754/2409-6105-2018-4-153-162

Fokin, A. A. (2013). '«Smekh v zale»: komicheskoe na partiinykh s'ezdakh (1950-1960-e gg.)' ["Laughter in the hall". The Comic during the party Congresses (1950-1960s)], in Narskiy I.(ed) Ot velikogo do smeshnogo... Instrumentalizatsiya smekha v rossiiskoi istorii $X X$ veka [From the great to the ridiculous... Instrumentalization of laughter in Russian history of the $20^{\text {th }}$ century]. Chelyabinsk: Kamenniy poyas, pp. 110-118.

Freedman, P. \& Spiegel G. (1998). 'Medievalisms old and new: The rediscovery of alterity'. North American Medieval Studies. The American Historical Review 103 (3), pp. 677-704.

Freidenberg, O. M. (1973/1926). 'The origin of parody'. Papers on Sign Systems 6, pp. 490497.

Freidenberg, O. M. (1976/1926). 'The origin of parody'. In: Baran, H. (ed) Semiotics and Structuralism: Readings from the Soviet Union. White Plains, N.Y. : International Arts and Sciences Press, pp. 269-283.

Freidenberg, O. (1997/1954). Image and Concept: Mythopoetic Roots of Literature. Amsterdam: Harwood Academic Publishers.

Friedrichs, J. (2001). 'The meaning of new medievalism'. European Journal of International Relations 7 (4), pp. 475-501.

Guibault, L. (1998). Limitations Found Outside Copyright Law, General Report Prepared for the ALAI Study Days. Retrieved January, 82021 from http://www.ivir.nl/medewerkers/guibault.html.

Grebenyuk, P. (2017). 'Laughter practice in public administration on the North-East of USSR (1940-1950s)'. Dialogue with Time 58, pp. 318-329.

Gorbachov, N. (2014). 'Normativity production in the discourse around the ban on "Homosexual Propaganda", in Kondakov, A. (ed.), Na pereputie: metodologia, teoria $i$ praktika LGBT $i$ kvir issledovaniy [At the crossroads: methodology, theory and practice of LGBT and queer studies], Saint Petersburg: Centre of Independent Sociological Studies, pp. 86-100.

Hutcheon, L. (2000). A Theory of Parody. The Teachings of Twentieth-Century Art Forms. Urbana and Chicago: University of Illinois Press. 
Höjdestrand, T. (2017). 'Nationalism and civicness in Russia: Grassroots mobilization in defense of 'family values', in Fabian, K. \& Korolczuk, E. (eds.), Rebellious Parents: Parental Movements in Central-Eastern Europe and Russia. Bloomington, Indianapolis: Indiana University Press, pp. 31-60.

Holsinger, B. (2007). Neomedievalism, Neoconservatism, and the War on Terror. Chicago: Prickly Paradigm Press.

Holsinger, B. (2008). 'Empire, Apocalypse, and the 9/11 premodern'. Critical Inquiry 34 (3), pp. 468-490.

Ioffe, I. (1934). Misteria i Opera (nemetskoe iskusstvo 16-18 vekov) [Mystery Play and Opera (German Art of the 16-18th centuries)]. Leningrad: Gosudarstvenniy muzykalniy nauchnoissledovatelskiy institut.

Ivanova, A., Stefanenko, E. \& Enikolopov, S. (2017). 'Russian attitudes towards humour and laughter'. The European Journal of Humour Research 5 (2), pp. 80-90.

Kasha, A. \& Hirschhorn, J. (1979). If They Ask You, You Can Write a Song. New York: Cornerstone Library.

Khapaeva, D. (2016). 'Triumphant memory of the perpetrators: Putin's politics of reStalinization'. Communist and Post-Communist Studies 49 (1), pp. 61-73.

Khapaeva, D. (2017). 'Neomedievalism as a future society: The case of Russia'. The Year's Work in Medievalism 32. Retrieved January, 82021 from https://www.sites.google.com/site/theyearsworkinmedievalism/all-issues/32-2017.

Khapaeva, D. (2019). 'The Gothic future of Eurasia'. Russian Literature 106, pp. 79-108.

Khvostunova, O. \& Voinova, E. (2009). 'Media changes in Russia: Threats, challenges, and prospects', in Vartanova, E., Nieminen, H. \& Salminen M.-M. (eds.), Perspectives to the Media in Russia: "Western" Interests and Russian Developments. Helsinki: University of Helsinki. Aleksanteri Series, 4/2009, pp. 187-197.

Kiremidjian, G. D. (1969). 'The aesthetics of parody'. Journal of Aesthetics and Art Criticism 28, pp. 231-242.

Kõiva, M. (ed.) (2009). Media \& Folklore. Contemporary Folklore IV. Tartu: ELM Scholarly Press.

Kondakov, A. (2018). 'Crip kinship: A political strategy of people who were deemed contagious by the shirtless Putin'. Feminist Formations 30 (1), pp. 71-90.

Kozintsev, A. G. (2008). 'On the anti-referential function of language', Arutiunova, N. D. (ed.). The Logical Analysis of Language. Between Lie and Fantasy. Moscow: Indrik, pp. 55-66.

Kozintsev, A. G. (2009). 'Stalin jokes and humor theory'. Russian Journal of Communication 2, (3/4), pp. 199-214.

Kozintsev, A. G. (2010). The Mirror of Laughter. New Brunswick, New Jersey: Routledge.

Kozintsev, A. G. (2013). 'Double-voiced discourse. Aestetics and semiotics of humor'. Antropologicheskij Forum 18, pp. 143-162.

Kolstø, P. \& Blakkisrud, H. (eds.) (2018). Russia Before and After Crimea: Nationalism and Identity, 2010-17. Edinburgh: Edinburgh University Press.

Krasner, S. (2001). 'Abiding sovereignty'. International Political Science Review / Revue Internationale De Science Politique 22 (3), pp. 229-251.

Krikmann, A. (ed.) (2004). Netinalju Stalinist - Internet-anekdoty o Staline - Internet Humour About Stalin. Tartu: Eesti Kirjandusmuuseum ja koostaja.

Krikmann, A. (2009). 'Jokes in Soviet Estonia'. Folklore 43, pp. 43-66.

Kucherenko, A. (2016). 'Some features of Arabic postfolklore in online communication'. Komunikacija i kultura online, Godina VII, broj 7, pp. 1-21.

Lai, A. (2019). The Right to Parody: Comparative Analysis of Copyright and Free Speech. Cambridge University Press. 
Lambiase, J. \& Reichert, T. (2003). 'Promises, promises: Exploring erotic rhetoric in sexually oriented advertising', in Scott, L. \& Batra, R. (eds.), Persuasive Imagery: A Consumer Response Perspective, Mahwah, NJ: Erlbaum. [Peer reviewed, 2000 Advertising \& Consumer Psychology Visual Persuasion Conference], pp. 247-266.

Logutov, A. (2017). 'Noise as the voice of power in the works of Franz Kafka'. Novoe Literaturnoe Obozrenie 6 (148), pp. 66-76.

Lunacharsky, A. (1964). 'Budem smeyatsya' [Let's laugh], in Lunacharsky, A. Collected Works, vol. 3. Moscow: Hudozhestvennaya Literatura, p. 76.

Lyan, I., Zidani, S., Shifman, L. (2015). 'When Gangnam hits the Middle East: Re-makes as identity practice'. Asian Communication Research 12 (2), pp. 10-31.

Marx K. (1977). Critique of Hegel's 'Philosophy of Right', Cambridge: Cambridge University Press.

Mendis, D. \& Kretschmer, M. (2013). The Treatment of Parodies under Copyright Law in Seven Jurisdictions: A Comparative Review of the Underlying Principles. The Intellectual Property Office. $\quad$ Retrieved January, 8021 from https://assets.publishing.service.gov.uk/government/uploads/system/uploads/attachment_d ata/file/309902/ipresearch-parody-report2-150313.pdf

Mohr, M. (2013). Holy Sh*t: A Brief History of Swearing. United Kingdom: Oxford University Press.

Muravyeva, M. (2014). “"(Non-)traditional sexual relationships” as a legal category: A historical legal analysis', in Kondakov, A. (ed.), Na pereputie: metodologia, teoria i praktika LGBT $i$ kvir issledovaniy [At the crossroads: methodology, theory and practice of LGBT and queer studies]. Saint Petersburg: Centre of Independent Sociological Studies, pp. 86-100.

Neckel, S. (2010). 'Refeudalisierung der Ökonomie: Zum Strukturwandel kapitalistischer Wirtschaft'. MPIfG Working Paper 10/6. Cologne: Max Planck Institute for the Study of Societies.

Nekludov, S. (1995). 'Posle folklore' [After Folklore]. Zhivaya starina 1, pp. 2-4.

Nekludov, S. (2002). 'Folklor: tipologicheskiy i kommunikativniy aspekty' [Folklore: Typological and Communicational aspects]. Traditsionnaya kul'tura [Traditional Culture] 3, pp. 3-7.

O'Callaghan, R. (2013). 'Secular theology and noble sacrifice: The ethics of Michael Walzer's just war theory'. Review of International Studies 39 (2), pp. 361-383.

O’Neill, M. (2001). Prostitution and Feminism. Cambridge: Polity Press.

Novitskaya, A. (2017). 'Patriotism, sentiment, and male hysteria: Putin's masculinity politics and the persecution of non-heterosexual Russians'. NORMA 12 (3-4), pp. 302-318.

Ouidade, S. \& Géraldine, M. (2014). 'When do advertising parodies hurt? The power of humor and credibility in viral spoof advertisements'. Journal of Advertising Research 54 (2), pp. 233-247.

Oushakine, S. (2011). 'Laughter under socialism: Exposing the ocular in Soviet jocularity'. Slavic Review 70 (2), pp. 247-255.

Pasti, S., Gavra, D. \& Anikina, M. (2015). 'New news media in Russia: What is new?', African Journalism Studies 36 (3), pp. 33-60.

Patriotic Mobilisation in Russia (2018). Europe Report N²51 (4 July). Brussels, International Crisis Group.

Pikulicka-Wilczewska, A. \& Sakwa, R. (eds.) (2015). Ukraine and Russia: People, Politics, Propaganda and Perspectives. Bristol: E-International Relations.

Plamper, J. (ed.) (2009). 'Emotional turn? Feelings in Russian history and culture'. Slavic Review 68 (2), pp. 229-237. 
Plamper, J., Schahadat, S., Marc, E. (eds.) (2010). Rossiiskaia imperiia chuvstv: Podkhody k kul'turnoi istorii emotsii [Russian Empire of Feelings. Approaches for Cultural History of Emotions]. Moscow: NLO.

Posner, R. A. (1992). 'When is parody fair use?'. The Journal of Legal Studies 21 (1), pp. 6778.

Propp, V. IA. (2009/1976). On the Comic and Laughter. Toronto, Buffalo, London: University of Toronto Press.

Robbins, B. (2019). 'Cosmopolitanism and the historical/contextual paradigm', in Ladegaard, J. \& Nielsen, J. (eds.), Context in Literary and Cultural Studies. London: UCL Press, pp. 17-36.

Robinson, C. L. \& Clements, P. (eds.) (2012). Neomedievalism in the Media: Essays on Film, Television and Electronic Games, Lewiston, NY: Edwin Mellen Press.

Rosselli A. \& Besomi D. (2005). 'The unlooked for proselytiser. J. Robinson and the correspondence with Sraffa, Harrod and Kaldor', in Rosselli A. \& Marcuzzo M. C. (eds.) Economists in Cambridge: A Study Through Their Correspondence, 1907-1946. London: Routledge, pp. 309-327.

Sánchez F. J. et al. (2009). 'Reported effects of masculine ideals on gay men'. Psychology of Men \& Masculinity 10 (1), pp. 73-87.

Savitskiy, E. (2015). "Novyi medivealizm" chetvert' veka spustya ["New medievalism" a quarter of a century later]. Novoe Literaturnoe Obozrenie 5 (135), pp. 346-354.

de Seta, G. (2020). 'Digital folklore', in Hunsinger J., Allen M. \& Klastrup L. (eds.), Second International Handbook of Internet Research. Springer, Dordrecht

Scheff, T. (2006). 'Hypermasculinity and violence as a social system'. Universitas 2 (2), pp. 110 .

Shifman, L. (2014). Memes in Digital Culture. Cambridge, MA: MIT Press.

Slepukhin, S. (2013). 'Motivy "Tantsa smerti" u Tomasa Manna' [Motifs of "Totentanz" in Thomas Mann's works]. Inostrannaya Literatura 8, pp. 233-264.

Smith, M. (2002). 'The flying phallus and the laughing inquisitor: Penis theft in the "Malleus Maleficarum"'. Journal of Folklore Research 39, 1, pp. 85-117.

Spector, J., ed. (2006). Prostitution and Pornography: Philosophical Debate About the Sex Industry. Stanford: Stanford University Press.

Sterne, L. (1760). 'House of Mourning and House of Feasting described', in Sterne, L. L. The Sermons of Mr. Yorick. London: R. and J. Dodsley [pt.1], pp. 45-46.

Shtorn, E. (2018). 'Murders of non-heterosexuals as a hate crime (Based on Court Decisions)'. Sociology of Power 30 (1), pp. 60-78.

Sychenkova, L. (2001). 'Ikonografija «Pljaski smerti». Odna istoricheskaja parallel' [Iconography "Dancing of death". A historical parallel]. Vestnik Mezhdunarodnogo instituta A. Bogdanova [Bulletin of International A. Bogdanov institute] 8. Retrieved August 8, 2016 from http://ec-dejavu.ru/d/Dance macabre.html.

Svetlov, R. (2015). 'Socrates in the context of the ancient imagination'. Schole. Ancient Philosophy and the Classical Tradition 9 (1), pp. 169-184.

Svetlov, R. (2019). 'Philosopher on a city street. ПPAЕHMA (PRAXEMA)'. Journal of Visual Semiotics 3, pp. 11-26.

Svetlov, R. \& Savchuk, V. (2017). 'Back to back: the double herm of Socrates and Seneca and "visual morality" in the Ancient world'. Schole. Ancient Philosophy and the Classical Tradition 11 (1), pp. 208-219

Tagangaeva, M. (2013). 'Political humor on Russian television'. Russian Analytical Digest No. 126, 10 April, pp. 11-16.

Troitskiy, S. (2006). 'Holy fools and buffoons as the media of "origin of the laugh"'. $\Delta o ́ \xi \alpha /$ Doxa 9, pp. 18-28. 
Troitskiy, S. (2008). 'Trickster: at the origins of laugh culture'. $\Delta$ ó $\xi \alpha$ / Doxa, 13, pp. 101-109.

Troitskiy, S. (2011). Laughter in Culture: Archaeology of the Phenomenon. Dusseldorf: LAP LAMBERT Academic Publishing.

Troitskiy, S. (2018). 'The function of sanction in Soviet children's literature'. Novoe Literaturnoe Obozrenie 4 (152), pp. 189-203.

Tynyanov, Yu. N. (1977a/1919). 'Dostoevsky and Gogol (towards a theory of parody)', in Tynyanov, Yu. N. Poetics. History of Literature. Cinema. Moscow: Nauka, pp. 198-226.

Tynyanov, Yu. N. (1977b/1929). 'On parody' in Tynyanov, Yu. N. Poetics. History of Literature. Cinema. Moscow: Nauka, pp. 284-310.

Vartanova, E. (2015) 'Russia: Post-Soviet, post-modern, post-empire', in Nordenstreng K. \& Thussu D. K. (eds.), Mapping BRICS Media. London: Routledge, pp. 125-144.

Whisnant, R. \& Stark, C. (eds.) (2004). Not for Sale: Feminists Resisting Prostitution and Pornography. North Melbourne, Victoria, Australia: Spinifex Press.

Wollenberg, D. (2018). Medieval Imagery in Today's Politics. Leeds: Arc Humanities Press.

Woodyard, K. M. (2014). 'Pussy Riot and the holy foolishness of punk'. Rock Music Studies 1 (3), pp. 268-286.

Zotov S., Mayzuls M., Harman D. (2018). Stradayushee Srednevekovie. Paradoksy Hristianskoi ikonografii [The Suffering Middle Ages. Paradoxes of Christian Iconography]. Moscow: AST. 